\title{
New-onset type 2 diabetes, elevated HbA1c, anti-diabetic medications, and risk of pancreatic cancer
}

\author{
Yunxia Lu ${ }^{*}, 1,2$, Luis Alberto García Rodríguez ${ }^{3}$, Linnéa Malgerud ${ }^{4}$, Antonio González-Pérez ${ }^{3}$, \\ Mar Martín-Pérez ${ }^{3}$, Jesper Lagergren ${ }^{1,5}$ and Tomas S Bexelius ${ }^{1,6}$ \\ ${ }^{1}$ Department of Molecular Medicine and Surgery, Karolinska Institutet, Stockholm 171 76, Sweden; ${ }^{2}$ Department of Epidemiology \\ and Biostatistics, Imperial College London, London W2 1PG, UK; ${ }^{3}$ Centro Español de Investigación Farmacoepidemiológica, \\ Madrid 28004, Spain; ${ }^{4}$ Department of Clinical Sciences, Intervention and Technology (CLINTEC), Karolinska Institutet, Stockholm \\ 171 77, Sweden; ${ }^{5}$ Division of Cancer Studies, Kinǵs College London, London WC2R 2LS, UK and ${ }^{6}$ Department of Medical \\ Epidemiology and Biostatistics, Karolinska Institutet, Stockholm 171 77, Sweden
}

Background: Associations between type 2 diabetes, anti-diabetic medications and pancreatic cancer are controversial. This study aims to clarify such associations with new-onset type 2 diabetes and repeated measurements of glycated haemoglobin (HbA1c) levels.

Methods: A nested case-control study was initiated from the Health Improvement Network (THIN) in UK from 1996 to 2010. Information of pancreatic cancer cases was retrieved electronically from the medical records and manually validated. Control subjects were randomly selected and frequency-matched to the cases on sex, age, and calendar years. Multivariable unconditional logistic regression was performed to estimate odds ratios (OR) and $95 \%$ confidence intervals (Cl), and adjusted for potential confounders.

Results: Among 1574768 person-years of follow-up, 529 pancreatic cancer cases and 5000 controls were identified. Type 2 diabetes, or changed $\mathrm{HbA} 1 \mathrm{c}$ levels (rather than $\mathrm{HbA} 1 \mathrm{c}$ levels at diabetes diagnosis) in diabetes patients ( $\geqslant 4 \mathrm{mmol} \mathrm{mol}^{-1}$ compared with $<0 \mathrm{mmol} \mathrm{mol}^{-1}$ ) were followed by an increased $\mathrm{OR}$ of pancreatic cancer $(\mathrm{OR}, 2.16,95 \% \mathrm{Cl} 1.72-2.72$ and $\mathrm{OR}, 5.06$, $95 \% \mathrm{Cl} 1.52-16.87$, respectively). Among the anti-diabetic medications in diabetes patients, the OR for insulin users was 25.57 (95\% $\mathrm{Cl} 11.55-56.60)$, sulphonylureas $2.22(95 \% \mathrm{Cl} 1.13,4.40)$, and metformin users $1.46(95 \% \mathrm{Cl} 0.85-2.52)$, compared with no use of any anti-diabetic medications.

Conclusions: New-onset type 2 diabetes and, particularly, diabetes with rising $\mathrm{HbA} 1 \mathrm{c}$ seem to be independent risk factors for pancreatic cancer. The relation between different anti-diabetic medications and pancreatic cancer seems to vary in strength, with the highest risk among users of insulin.

There is an elevated risk of pancreatic cancer among patients with type 2 diabetes. It is unclear, however, whether it is the diabetes per se or its treatment that explains this association (Ben et al, 2011; Elena et al, 2013; Bosetti et al, 2014). Furthermore, diabetes is postulated as a manifestation of pancreatic cancer in some studies, which makes the association even more complex. Further research on incident type 2 diabetes and the risk of subsequently diagnosed pancreatic cancer is therefore necessary.

Several mechanisms have been suggested by which diabetes might promote pancreatic cancer. First, diabetes is typically

*Correspondence: Dr Y Lu; E-mail: yunxia.lu@ki.se

Received 23 June 2015; revised 4 September 2015; accepted 14 September 2015; published online 17 November 2015

(c) 2015 Cancer Research UK. All rights reserved 0007-0920/15 
preceded by a long period of insulin resistance with a compensatory hyperinsulinaemia and hyperglycaemia, which may promote carcinogenesis. High circulating levels of insulin, glycated haemoglobin (HbAlc), a form of haemoglobin that reflects the average plasma glucose concentration over prolonged periods of time (8-12 weeks), or C-peptide (a component of proinsulin used as a marker of endogenous insulin production) in diabetic patients might increase pancreatic cancer risk (Stolzenberg-Solomon et al, 2005; Michaud et al, 2007; Grote et al, 2011; Wolpin et al, 2013). Second, obesity is a risk factor for both diabetes and pancreatic cancer, which might be in the causal pathway. However, diabetes has not only been associated with obesity-related cancers, for example, breast cancer, hepatocellular carcinoma and endometrial cancer (El-Serag et al, 2006; Friberg et al, 2007; Boyle et al, 2012) but also those that are non-obesity related, for example, lung and gastric cancers (Lee et al, 2013; Yoon et al, 2013). This indicates an independent role of diabetes in cancer development. Third and lastly, some diabetic medications have been associated with a risk of pancreatic cancer (Singh et al, 2013; Wang et al, 2014; Kowall et al, 2015; Walker et al, 2015).

Observational studies of diabetes and anti-diabetic medications in relation to pancreatic cancer probably have been afflicted with time-related bias and confounding by indication (Kowall et al, 2015). The aim of the present study was to disentangle the roles of diabetes, HbA1c levels in diabetics, and anti-diabetic medications in relation to pancreatic cancer risk in a prospective cohort with validated data from the Health Improvement Network (THIN) in UK.

\section{MATERIALS AND METHODS}

Population and study design. This nested case-control study was based on information from the THIN database in UK, which has been described in detail elsewhere (Sjoberg Bexelius et al, 2009; Gonzalez-Perez et al, 2010). Briefly, THIN is a UK database with longitudinally collected data from computerised primary care medical records, including diagnostic and prescribing information recorded by general practitioners (GPs) during their routine health care practice. The study cohorts were identified from 1 January 1996 through 31 December 2006, and followed up until 31 December 2010. The flow chart of study design is shown in Figure 1. Eligible participants ranged from 20 to 79 years of age. Those with a history of cancer (other than non-melanoma skin cancer) or any pancreatic disease prior to entering the study were excluded. The exclusion was based on READ codes compatible with cancer or pancreatic disease (including any form of pancreatitis and assessment of amylase values) recorded before

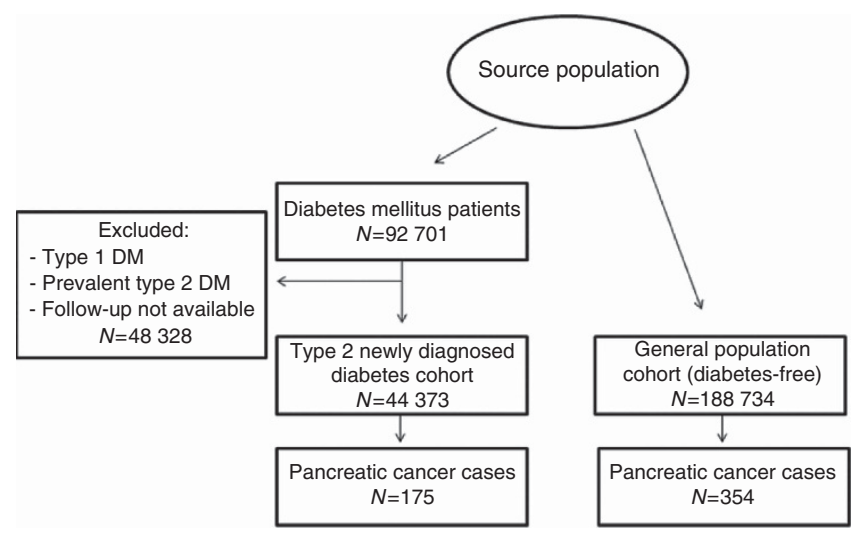

Figure 1. Flow chart of the study design. entering the cohort. Two cohorts, a type 2 newly diagnosed diabetes cohort $(N=44373)$ and a non-diabetic general population cohort $(N=188734)$, were identified from the source population. Ascertainment of the diabetes cohort is described in greater detail in our previous study (Gonzalez-Perez et al, 2010). Briefly, we ascertained all patients within the study base with a READ code of diabetes recorded in the database based on type-specific READ codes (i.e., those that denote explicitly the type of diabetes), the age at diagnosis and the lifetime history of anti-diabetic pharmacological treatment. Among those within the type 2 diabetes cohort, we defined as newly diagnosed diabetes those with the first code compatible with diabetes recorded within the cohort enrolment period. The general population cohort had not only the same eligibility criteria as the type 2 newly diagnosed diabetes cohort but also the additional condition that the individuals had to be free of a recorded diagnosis of diabetes before the start of the study.

Ascertainment of pancreatic cancer cases and controls. All members in the diabetes cohort and the general population cohort were followed up from the date of entry until incident pancreatic cancer, death, or end of the study period (31 December 2010), whichever occurred first. The incident cases of pancreatic cancer were individuals with a first READ code of pancreatic cancer recorded during the follow-up period. To ascertain the pancreatic cancer diagnosis, we manually reviewed the computerised patient profiles (TSB, LM, YL and LGR) after incorporating data from free-text comments, that is, medical notes from the GP's (comments either originate directly from the GP or contain information received from secondary/tertiary care). The initial number of potential pancreatic cancer cases was 544 (179 cases in the type 2 diabetes cohort and 365 in the general population cohort). After exclusion of unconfirmed or prevalent cases (four from the type 2 diabetes cohort and 11 from the general population cohort), 529 patients were retained as incident pancreatic cancer cases for final analysis. Their date of diagnosis was used as the index date.

Incidence density sampling of controls was performed by generating a random date within the study period for each individual among the two study cohorts in whom pancreatic cancer cases were ascertained. If the random date fell within the study member's follow-up contribution time, this person was marked as an eligible control and the random date was used as the index date. A group of 5000 control subjects was randomly selected from the list of eligible controls and frequency-matched to the case subjects on sex, age ( \pm 1 year) and the calendar year.

Identification and categorisation of HbAlc levels. Repeated measurements of $\mathrm{HbAlc}$ were retrieved from the medical records for all diabetic patients. We focused on two measurements of $\mathrm{HbA} 1 \mathrm{c}$, one measured closest to the date of the diabetes diagnosis (within 12 weeks after the date of diagnosis of type 2 diabetes) that represents the starting level of HbAlc in diabetic patients, and another measured closest to the date of diagnosis of pancreatic cancer or the index date for controls (within 12 weeks before the index date) that represents the $\mathrm{HbAlc}$ level at the time of diagnosis. Because human red blood cells survive for 8-12 weeks (before continuous renewal), HbAlc is used clinically as a reflection of average blood glucose levels over that period of time. HbAlc was categorised into three groups (normal $<42 \mathrm{mmol} \mathrm{mol}^{-1}$, high $42-47 \mathrm{mmol} \mathrm{mol}^{-1}$ or very high $\geqslant 48 \mathrm{mmol} \mathrm{mol}^{-1}$ ) based on UK public health guidelines for the identification of individuals at risk of diabetes (Farmer, 2012). The difference between the two measurements was grouped into $<0,0-4$, or $\geqslant 4 \mathrm{mmol} \mathrm{mol}^{-1}$.

Identification and definition of anti-diabetic drug use. The assessment of anti-diabetic drugs included the following four groups: insulin, metformin, sulfonylureas and glitazones. These 
medication groups were identified by reviewing medical records. Other anti-diabetic drugs (meglitinides, glucagon-like peptide-1 (GLP-1) and gliptins) were less commonly used by the patients in the current study period and were therefore not included in the analyses. Any of the studied anti-diabetic drug groups were categorised into four patterns of use: non-use (no recorded use between start date and index date), current use (the most recent prescription lasted until the index date or ended within 90 days before it), recent and past use (the most recent prescription ended between 91 and 365 days before the index date and the most recent prescription ended more than 365 days before the index date but occurred after the start date). Duration of current use was further divided into three categories: $<1,1-3$ or $>3$ years. Time from the date of diabetes diagnosis to the index date was grouped into: $<1$, $1-2,2.1-5$ or $>5$ years.

Identification of covariates. The following covariates were retrieved from the medical records and considered in the analyses: age; sex; body mass index (BMI); tobacco smoking; alcohol drinking; Townsend deprivation index (a measure of social economic status using five-level score whereby a high value indicates a high level of deprivation); and number of GP visits 1 year before the index date (which was highly related to general comorbidity and used as a proxy for comorbidity).

Statistical analyses. The main analysis was based on a nested case-control design. Using unconditional logistic regression, odds ratios (OR) and $95 \%$ confidence intervals (CI) were calculated to assess the relative risk of developing pancreatic cancer with regards to the different study exposures, that is, diabetes, time from diabetes diagnosis, HbAlc levels at diabetes diagnosis or before pancreatic cancer diagnosis, increase in $\mathrm{HbAlc}$ levels and use of anti-diabetic medications (only use of metformin, only use of sulphonylureas, any use of insulin, combination of oral antidiabetic medications and no use of any anti-diabetic medication). Two statistical models were employed. The basic model included adjustment for age and sex (calendar year and time from diabetes diagnosis whenever appropriate). In the full model, we further adjusted for tobacco smoking status (categorised into non-smoker, current smoker, former smoker or unknown), alcohol intake (nonuser, $1-9,10-20,21-41, \geqslant 42$ units per week or unknown), BMI $(<20,20-24.99,25-29.99$ or $\geqslant 30)$, Townsend deprivation index (five categories from least to most deprived, or unknown) and time from diabetes diagnosis when appropriate. Sub-group analyses were performed to assess the risk of pancreatic cancer in diabetic patients.

To reduce selection bias due to sub-clinical pancreatic cancer stages, the first year of follow-up was excluded from the analysis as a sensitivity analysis (results shown in Supplementary Tables). In addition, person-time at risk in each study cohort was classified across strata by age, sex, and calendar year. Age and sex-specific incidence rates of pancreatic cancer were calculated using the corresponding person-years.

All analyses were performed using the SAS Statistical Package (version 9.0, SAS Institute Inc., Gary, NC, USA). All tests were two-sided with a significance level of 0.05 . The study was approved by the UK Research Ethics Committee and the Regional Ethical Review Board in Stockholm.

\section{RESULTS}

Participants. Overall, 529 incident pancreatic cancer cases occurred in 1574768 person-years of follow-up. The incidence of pancreatic cancer was 74.7 per 100000 person-years in the diabetes cohort and 25.0 per 100000 person-years in the general population cohort. The average time between first recorded diagnosis of diabetes and occurrence of pancreatic cancer among the 175 cases in the diabetes cohort was 2.46 years $($ s.d. $=2.50)$.
Table 1. Basic characteristics of pancreatic cancer cases and controls

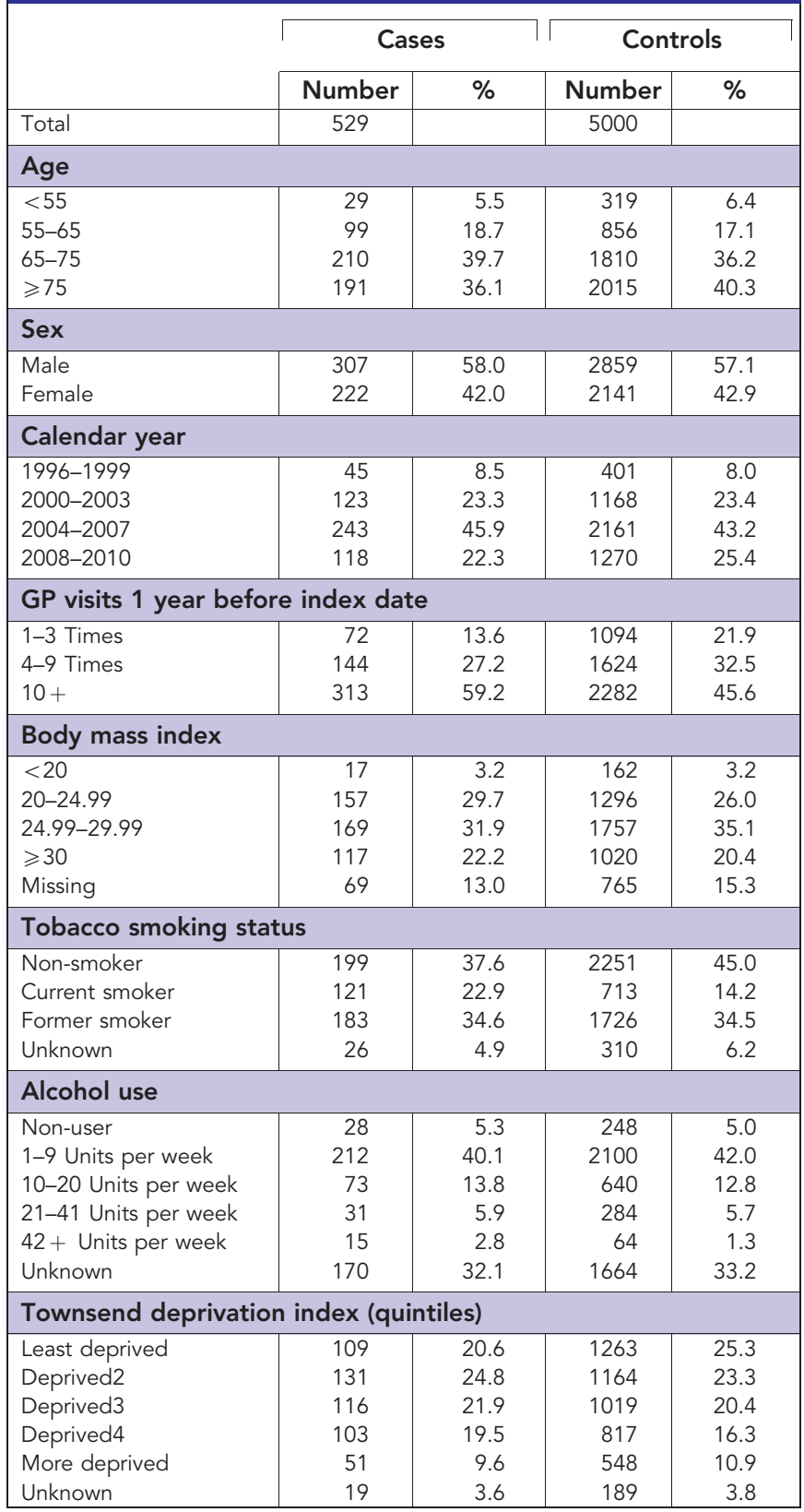

Some characteristics of cases and controls are presented in Table 1. Age, sex, calendar year and BMI were similarly distributed in cases and controls, while the cases had a higher prevalence of current smokers, increased alcohol consumption, and were more socioeconomically deprived (Townsend deprivation index). The cases also had more GP visits in the past year.

Type 2 diabetes and risk of pancreatic cancer. Individuals with newly diagnosed type 2 diabetes were associated with an increased risk of pancreatic cancer (OR 2.16, 95\% CI, 1.72, 2.72) compared with non-diabetic individuals (Table 2). The association was strongest during the first year after the diabetes diagnosis (OR 5.30, $95 \% \mathrm{CI}, 2.83,9.93)$ when using more than 5 years after diagnosis as the reference category and declined 1-2 years following the diagnosis (OR 3.30, 95\% CI, 1.72, 6.23) (Table 2). A sharply decreased incidence rate of pancreatic cancer was observed in the diabetes cohort over time, which was not found in the non-diabetic cohort (Figure 2). The association between diabetes and pancreatic 
Table 2. Diabetes, glycated haemoglobin (HbA1c) and risk of pancreatic cancer, expressed as $\mathrm{OR}$ with $95 \% \mathrm{Cl}$

\begin{tabular}{|c|c|c|c|c|}
\hline & Cases & Controls & $\begin{array}{l}\text { Basic model } \\
\text { OR }(95 \% \mathrm{Cl})\end{array}$ & $\begin{array}{l}\text { Full model } \\
\text { OR }(95 \% \mathrm{Cl})\end{array}$ \\
\hline \multicolumn{5}{|l|}{ Diabetes } \\
\hline $\begin{array}{l}\text { No } \\
\text { Yes }\end{array}$ & $\begin{array}{l}354 \\
175\end{array}$ & $\begin{array}{r}4144 \\
856\end{array}$ & $\begin{array}{c}\text { Reference } \\
2.36(1.94,2.89)\end{array}$ & $\begin{array}{c}\text { Reference } \\
2.16(1.72,2.72)\end{array}$ \\
\hline \multicolumn{5}{|l|}{ Among/within diabetes patients } \\
\hline $\begin{array}{l}\text { Time from diabetes diagnosis date to index date } \\
<1 \text { year } \\
1-2 \text { years } \\
2-5 \text { years } \\
>5 \text { years }\end{array}$ & $\begin{array}{l}66 \\
36 \\
48 \\
25\end{array}$ & $\begin{array}{l}170 \\
137 \\
345 \\
204\end{array}$ & $\begin{array}{c}3.43(2.06,5.72) \\
2.28(1.31,4.00) \\
1.20(0.71,2.01) \\
\text { Reference }\end{array}$ & $\begin{array}{c}5.30(2.83,9.93) \\
3.30(1.72,6.33) \\
1.45(0.82,2.55) \\
\text { Reference }\end{array}$ \\
\hline $\begin{array}{l}\text { HbA1c at diagnosis of diabetes } \\
\text { Normal }\left(<42 \mathrm{mmol} \mathrm{mol}^{-1}, \text { or }<6.0 \%\right) \\
\text { High }\left(42-47 \mathrm{mmol} \mathrm{mol}^{-1}, \text { or } 6.0-6.5 \%\right) \\
\text { Very high }\left(>47 \mathrm{mmolmol}^{-1},>6.5 \%\right)\end{array}$ & $\begin{array}{r}14 \\
6 \\
63\end{array}$ & $\begin{array}{r}78 \\
49 \\
280\end{array}$ & $\begin{array}{c}\text { Reference } \\
0.56(0.20,1.57) \\
1.18(0.62,2.26)\end{array}$ & $\begin{array}{c}\text { Reference } \\
0.57(0.19,1.70) \\
1.02(0.51,2.03)\end{array}$ \\
\hline $\begin{array}{l}\text { HbA1c at index date } \\
\text { Normal }\left(<42 \mathrm{mmol} \mathrm{mol}^{-1} \text {, or }<6.0 \%\right) \\
\text { High }\left(42-47 \mathrm{mmol} \mathrm{mol}^{-1} \text {, or } 6.0-6.5 \%\right) \\
\text { Very high }\left(>47 \mathrm{mmol} \mathrm{mol}^{-1} \text {, or }>6.5 \%\right)\end{array}$ & $\begin{array}{r}15 \\
6 \\
69\end{array}$ & $\begin{array}{r}75 \\
56 \\
193\end{array}$ & $\begin{array}{c}\text { Reference } \\
0.57(0.20,1.57) \\
1.97(1.05,3.71)\end{array}$ & $\begin{array}{c}\text { Reference } \\
0.51(0.17,1.54) \\
1.85(0.91,3.73)\end{array}$ \\
\hline $\begin{array}{l}\text { Difference between the two } \mathrm{HbA} 1 \mathrm{c} \text { measurements } \\
\quad<0 \mathrm{mmol} \mathrm{mol}^{-1} \\
0-4 \mathrm{mmol} \mathrm{mol}^{-1} \\
\geqslant 4 \mathrm{mmol} \mathrm{mol}^{-1}\end{array}$ & $\begin{array}{r}17 \\
27 \\
8\end{array}$ & $\begin{array}{r}104 \\
61 \\
14\end{array}$ & $\begin{array}{c}\quad \text { Reference } \\
2.55(1.24,5.24) \\
3.90(1.36,11.19)\end{array}$ & $\begin{array}{l}\quad \text { Reference } \\
3.22(1.39,7.45) \\
5.06(1.52,16.87)\end{array}$ \\
\hline \multicolumn{5}{|c|}{ 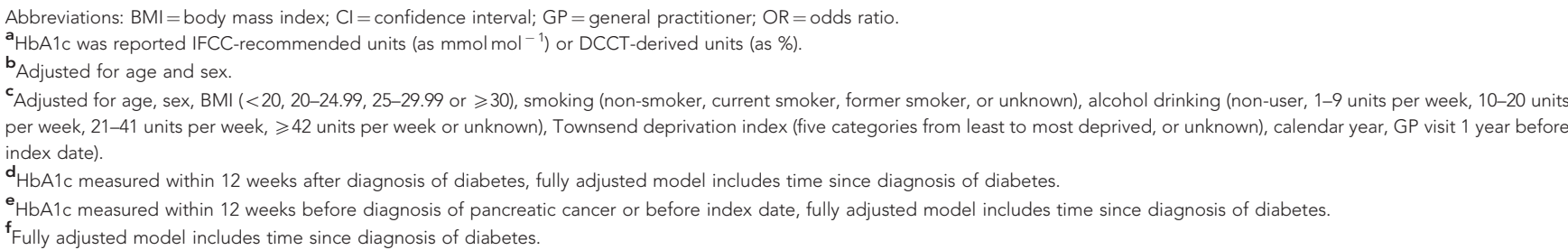 } \\
\hline
\end{tabular}

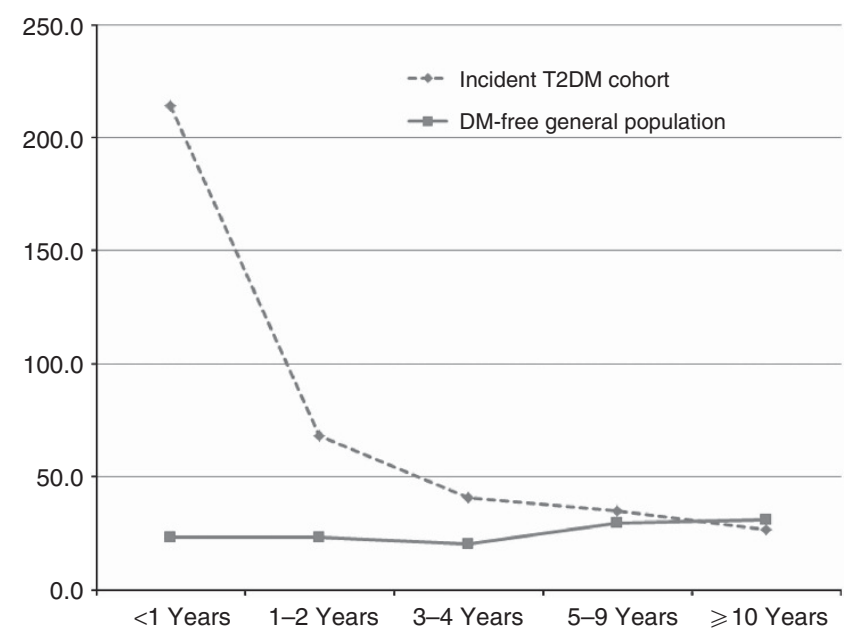

Figure 2. Incidence rate (per 100000 ) of pancreatic cancer cases since index date in incident diabetes cohort and diabetes-free general population cohort.

cancer remained two-fold increased after excluding the first year of follow-up (OR 2.04, 95\% CI, 1.56, 2.66). Detailed results for the analysis, excluding the first year of follow-up, are available in Supplementary Table 1.

HbA1c and risk of pancreatic cancer. Non-significant associations with pancreatic cancer were found among participants with higher HbAlc levels ( $\geqslant 48$ compared with $<42 \mathrm{mmol} \mathrm{mol}^{-1}$ ) measured close to the diabetes diagnosis (OR 1.02, 95\% CI, 0.51, 2.03), and HbAlc measured close to the index date (OR 1.85, 95\% CI, $0.91,3.73$ ) (Table 2). The change of HbAlc between the aforementioned two measurements (the last measurement minus the first measurement with a difference $\geqslant 4 \mathrm{mmol} \mathrm{mol}^{-1} \mathrm{com}$ pared with $<0 \mathrm{mmol} \mathrm{mol}^{-1}$ ) was associated with an increased OR of pancreatic cancer (OR 5.06, 95\% CI, 1.52, 16.86) (Table 2).

Anti-diabetic medication and risk of pancreatic cancer. In Table 3, diabetes and use of metformin showed an increased OR compared with non-diabetes and no use of metformin (OR 2.63, $95 \%$ CI, 1.99, 3.46). Although for participants who had diabetes and no use of metformin compared with the aforementioned same controls, the quantity of OR seemed to decrease but the difference was not significant. Similar patterns have been observed for sulphonylureas, glitazones and insulin. However, in sulphonylureas or insulin users, diabetes plus relevant medications showed a significantly increased OR compared with diabetes without the relevant medication (for sulphonylureas OR, 3.39, 95\% CI, 2.54, 4.54 and 1.56, 95\% CI, 1.18, 2.07; for insulin, OR, 10.15, 95\% CI, $5.95,17.32$ and $1.85,95 \% \mathrm{CI}, 1.45,2.36)$.

Compared with non-users, ever use (current, recent and past use) of metformin had an increased OR (OR 1.44, 95\% CI, 1.01, 2.06; OR 2.05, 95\% CI, 1.15, 3.65 for current use, and recent and past use, respectively). This association was similar in other antidiabetic medications, although results of insulin might be less reliable because of too few cases. In diabetic participants, no significant results were found regarding the association between duration of use of anti-diabetic medications and risk of pancreatic cancer.

Further analyses in the diabetic participants are shown in Table 4. When compared with no use of any anti-diabetic medications, the OR for only use of metformin was 1.46 (95\% CI, 0.85, 2.52), sulphonylureas was 2.22 (95\% CI, 1.13, 4.40), any use of insulin was 25.57 (95\% CI, 11.55, 56.60), combinations of oral anti-diabetic medications (use of two or more oral medications) was 4.84 (95\% CI, 2.84, 8.22). Similar results were observed 
Table 3. Anti-diabetic medications and risk of pancreatic cancer, expressed as OR with $95 \% \mathrm{Cl}$

\begin{tabular}{|c|c|c|c|c|}
\hline & $\begin{array}{c}\text { Cases } \\
n\end{array}$ & $\begin{array}{c}\text { Controls } \\
n\end{array}$ & $\begin{array}{l}\text { Basic model } \\
\text { OR }(95 \% \mathrm{Cl})\end{array}$ & $\begin{array}{l}\text { Full model } \\
\text { OR }(95 \% \mathrm{Cl})\end{array}$ \\
\hline \multicolumn{5}{|l|}{ Metformin } \\
\hline Non-diabetes, no use of metformin & 354 & 4144 & Reference & Reference \\
\hline *Diabetes, no use of metformin & 67 & 412 & $1.88(1.42,2.50)$ & $1.72(1.27,2.33)$ \\
\hline Diabetes, use of metformin & 108 & 444 & $2.82(2.22,3.59)$ & $2.63(1.99,3.46)$ \\
\hline Non-use & 421 & 4556 & Reference & Reference \\
\hline Current use (0-90) & 88 & 383 & $2.43(1.88,3.14)$ & $1.44(1.01,2.06)$ \\
\hline Recent and past use $(90+)$ & 20 & 61 & $3.49(2.09,5.86)$ & $2.05(1.15,3.65)$ \\
\hline \multicolumn{5}{|l|}{ Current use ${ }^{c}$} \\
\hline$<1$ Year & 43 & 137 & Reference & Reference \\
\hline 1-3 Years & 28 & 139 & $0.86(0.49,1.53)$ & $0.85(0.45,1.59)$ \\
\hline$\geqslant 3$ Years & 17 & 107 & $1.06(0.49,2.29)$ & $0.98(0.43,2.26)$ \\
\hline \multicolumn{5}{|l|}{ Sulphonylureas } \\
\hline Non-diabetes, no use of sulphonylureas & 352 & 4140 & Reference & Reference \\
\hline Diabetes, no use of sulphonylureas & 84 & 575 & $1.69(1.31,2.19)$ & $1.56(1.18,2.07)$ \\
\hline Diabetes, use of sulphonylureas & 91 & 281 & $3.76(2.89,4.89)$ & $3.39(2.54,4.54)$ \\
\hline Non-use & 436 & 4715 & Reference & Reference \\
\hline Current use (0-90) & 76 & 228 & $3.53(2.67,4.67)$ & $2.30(1.62,3.26)$ \\
\hline Recent and past use $(90+)$ & 17 & 57 & $3.15(1.81,5.47)$ & $2.03(1.12,3.68)$ \\
\hline \multicolumn{5}{|l|}{ Current use ${ }^{c}$} \\
\hline$<1$ year & 44 & 79 & Reference & Reference \\
\hline $1-3$ years & 20 & 77 & $0.61(0.31,1.19)$ & $0.57(0.26,1.25)$ \\
\hline$\geqslant 3$ years & 10 & 71 & $0.42(0.17,1.04)$ & $0.42(0.14,1.21)$ \\
\hline \multicolumn{5}{|l|}{ Glitazones } \\
\hline Non-diabetes, no use of glitazones & 354 & 4144 & Reference & Reference \\
\hline Diabetes, no use of glitazones & 143 & 760 & $2.18(1.76,2.69)$ & $1.99(1.57,2.54)$ \\
\hline Diabetes, use of glitazones & 32 & 96 & $3.88(2.56,5.90)$ & $3.63(2.33,5.68)$ \\
\hline Non-use & 497 & 4904 & Reference & Reference \\
\hline Current use (0-90) & 24 & 70 & $3.30(2.05,5.30)$ & $1.88(1.13,3.14)$ \\
\hline Recent and past use $(90+)$ & 8 & 26 & $2.95(1.33,6.55)$ & $1.66(0.73,3.78)$ \\
\hline \multicolumn{5}{|l|}{ Current use $^{c}$} \\
\hline$<1$ year & 16 & 37 & Reference & Reference \\
\hline$\geqslant 1$ years & 8 & 33 & $1.06(0.33,3.49)$ & $7.09(0.37,136.96)$ \\
\hline \multicolumn{5}{|l|}{ Insulin } \\
\hline Non-diabetes, no use of insulin & 354 & 4143 & Reference & Reference \\
\hline Diabetes, no use of insulin & 144 & 825 & $2.02(1.63,2.50)$ & $1.85(1.45,2.36)$ \\
\hline Diabetes, use of insulin & 31 & 31 & $11.59(6.95,19.34)$ & $10.15(5.95,17.32)$ \\
\hline Non-use & 498 & 4968 & Reference & Reference \\
\hline Current use (0-90) & 29 & 31 & $9.08(5.42,15.21)$ & $5.13(2.97,8.86)$ \\
\hline Recent and past use $(90+)$ & 2 & 1 & $19.31(1.74,214.00)$ & $11.12(0.95,130.06)$ \\
\hline \multicolumn{5}{|l|}{ Current use $^{c}$} \\
\hline$<1$ year & 19 & 11 & Reference & Reference \\
\hline$\geqslant 1$ years & 10 & 20 & $0.50(0.12,2.10)$ & $0.71(0.02,33.60)$ \\
\hline \multicolumn{5}{|c|}{$\begin{array}{l}\text { Abbreviations: } \mathrm{Cl}=\text { confidence interval; } \mathrm{GP}=\text { general practitioner; } \mathrm{OR}=\text { odds ratio. } \\
\text { a Adjusted for age and sex. } \\
{ }^{\mathrm{b}} \text { Adjusted for age, sex, body mass index }(<20,20-24.99,25-29.99, \text { or } \geqslant 30) \text {, smoking (non-smoker, current smoker, former smoker or unknown), alcohol drinking (non-user, 1-9, 10-20, 21-41, } \\
\geqslant 42 \text { units per week or unknown), Townsend deprivation index (five categories from least to most deprived, or unknown), calendar year, GP visit } 1 \text { year before index date) and diabetes (when } \\
\text { appropriate for anti-diabetics). } \\
{ }^{c} \text { Analysis within diabetes, adjusted for age, sex, body mass index, smoking, alcohol drinking, Townsend deprivation index, calendar year, GP visit } 1 \text { year before index date and time since } \\
\text { diagnosis of diabetes. }\end{array}$} \\
\hline
\end{tabular}

for diabetes diagnosed within one year. For diabetes diagnosed $\geqslant 1$ year, the risk of only use of sulphonylureas became non-significant (OR 1.07, 95\% CI, 0.35, 3.27) (Table 4).

\section{DISCUSSION}

This study suggests that new-onset diabetes is associated with an increased risk of pancreatic cancer, especially early after the diagnosis, which is a finding supported by the association between elevated $\mathrm{HbA} 1 \mathrm{c}$ levels and an increased risk of pancreatic cancer. Anti-diabetic medications showed different associations to the risk of pancreatic cancer, with an increased risk of pancreatic cancer present in insulin users and the least increased risk seen in metformin users.

Previous studies have also found diabetes to be associated with pancreatic cancer (Ben et al, 2011; Elena et al, 2013). However, the majority of prior epidemiological studies have evaluated longstanding diabetes as a possible causative or inductive factor for subsequent pancreatic cancer (Boyle et al, 2012; Bosetti et al, 2014), while, in our study, we have instead chosen to focus on new-onset diabetes. Although an analysis excluding the first year following the diabetes diagnosis attenuated the association, a statistically significant association remained. Hyperinsulinaemia and insulin 
Table 4. Risk of pancreatic cancer in diabetes patients associated with use of different anti-diabetic medications, expressed as OR with $95 \% \mathrm{Cl}$

\begin{tabular}{|c|c|c|c|c|}
\hline & Cases & Control & OR $(95 \% \mathrm{Cl})^{\mathrm{a}}$ & OR $(95 \% \mathrm{Cl})^{\mathrm{b}}$ \\
\hline \multicolumn{5}{|l|}{ All diabetes } \\
\hline Only use of metformin & 30 & 215 & $1.44(0.86,2.42)$ & $1.46(0.85,2.52)$ \\
\hline Only use of sulphonylureas & 19 & 85 & $2.00(1.08,3.69)$ & $2.22(1.13,4.40)$ \\
\hline Any use of insulin & 31 & 31 & $21.79(10.71,44.30)$ & $25.57(11.55,56.60)$ \\
\hline Use of two or more medications except insulin & 56 & 204 & $4.65(2.84,7.61)$ & $4.84(2.84,8.22)$ \\
\hline No use of any anti-diabetic medications & 39 & 321 & Reference & Reference \\
\hline \multicolumn{5}{|l|}{ Less than 1 year from diagnosis of diabetes } \\
\hline Only use of metformin & 13 & 44 & $1.56(0.70,3.48)$ & $1.59(0.66,3.83)$ \\
\hline Only use of sulphonylureas & 14 & 21 & $3.36(1.44,7.86)$ & $3.78(1.38,10.35)$ \\
\hline Any use of insulin & 6 & 1 & $29.59(3.34,262.46)$ & $31.15(2.73,356.13)$ \\
\hline Use of two or more medications except insulin & 14 & 11 & $6.78(2.61,17.63)$ & $8.00(2.73,23.47)$ \\
\hline No use of any anti-diabetic medications & 19 & 93 & Reference & Reference \\
\hline \multicolumn{5}{|c|}{ More than 1 year from diagnosis of diabetes } \\
\hline Only use of metformin & 17 & 171 & $1.38(0.69,2.74)$ & $1.41(0.68,2.93)$ \\
\hline Only use of sulphonylureas & 5 & 64 & $0.96(0.34,2.71)$ & $1.07(0.35,3.27)$ \\
\hline Any use of insulin & 25 & 30 & $16.34(7.56,35.29)$ & $18.25(7.50,44.41)$ \\
\hline Use of two or more medications except insulin & 42 & 193 & $4.00(2.18,7.35)$ & $3.91(2.00,7.64)$ \\
\hline No use of any anti-diabetic medications & 20 & 228 & Reference & Reference \\
\hline \multicolumn{5}{|c|}{$\begin{array}{l}\text { Abbreviations: } \mathrm{Cl}=\text { confidence interval; } \mathrm{GP}=\text { general practitioner; } \mathrm{OR}=\text { odds ratio. } \\
{ }^{\text {a }} \text { Adjusted for age, sex and time since diagnosis of diabetes. } \\
\text { b } \\
\text { bdjusted for age, sex, time from diagnosis of diabetes, body mass index, calendar year, smoking, alcohol drinking, physical activity, GP visit } 1 \text { year before index date and Townsend } \\
\text { deprivation index. }\end{array}$} \\
\hline
\end{tabular}

resistance may be key factors in the development of pancreatic cancer. Diabetic patients show a progressive metabolic disorder, from pre-diabetes to diabetes and, finally, to the late stages of diabetes with severe comorbidities that could affect the risk of many cancers (Hsueh et al, 2010; Tabak et al, 2012). Subjects who have had diabetes for many years are more likely to have reached the point of pancreatic exhaustion, which results in a gradually declining insulin production, and therefore might be experiencing a status of hypoinsulinemia. This seemed to be consistent with the negative association between the duration of diabetes and pancreatic cancer in this study. Previous studies were generally based on self-reported diabetes, which might lead to misclassification of the exposed with respect to the hypothesised biological mechanism linking new-onset diabetes and cancer (Flood et al, 2010; Onitilo et al, 2013).

Furthermore, the present study showed that increasing HbAlc levels, which potentially indicate increased severity of diabetes, was associated with a three-fold or more increased risk of pancreatic cancer compared with diabetic patients with low changes of $\mathrm{HbAlc}$ levels after diabetes diagnosis. This result may further corroborate the pivotal role of new-onset diabetes with typical hyperglycaemia in the development of pancreatic cancer. Few studies reported the association between change of $\mathrm{HbAlc}$ in diabetes and pancreatic cancer. HbA1c reflects average blood sugar levels over a period of weeks/months. Some studies have demonstrated that improving HbAlc for people with types 1 or 2 diabetes cuts the risk of microvascular complications. Therefore deterioration of $\mathrm{HbAlc}$ may increase the risk of diabetes complications, including cancer. Although limited number of existing studies examined the role of elevated HbA1c on pancreatic cancer (Grote et al, 2011; Wolpin et al, 2013), the increased HbA1c levels indicate poorly controlled diabetes, which, reasonably, contributes to the metabolic derangement that may lead to pancreatic cancer development.

Controversy does exist, however, regarding the role of diabetes in pancreatic cancer as $50-80 \%$ of patients with this cancer have concomitant diabetes, which often predates the diagnosis of cancer by 1 to 2 years (Pannala et al, 2008). Epidemiological evidence shows that patients with newly diagnosed diabetes have a higher detection rate of pancreatic cancer (Pannala et al, 2009), which was indicated in the present study as well. The new-onset diabetes in pancreatic cancer is possibly a paraneoplastic phenomenon caused by tumour-secreted products. This notion was strengthened by recent studies that proposed adrenomedullin, an amino-acid polypeptide, as a strong candidate for a mediator of diabetes in pancreatic cancer (Aggarwal et al, 2012; Sah et al, 2013). Other studies have supported the assertion that diabetes may be a marker for pancreatic cancer in some individuals (Giovannucci et al, 2010). Diabetes associated with pancreatic cancer may result from insulin resistance induced by a paraneoplastic syndrome or pancreatic cancer associated cell dysfunction in insulin production. Animal studies suggest that glucose intolerance may be an early feature of pancreatic cancer (Chari, 2014). Hyperglycaemia induced by pancreatic cancer in human beings can be cured or ameliorated by surgical resection of the pancreatic tumour.

The role of anti-diabetic medication in pancreatic cancer aetiology has been proposed to either increase the risk of cancer (insulin) or ameliorate the risk (metformin) (Evans et al, 2005; Bowker et al, 2006; Elena et al, 2013; Karlstad et al, 2013; Wang et al, 2014; Kowall et al, 2015; Walker et al, 2015) but results are inconsistent (Soranna et al, 2012; Karlstad et al, 2013; Singh et al, 2013). Two meta-analyses on metformin and pancreatic cancer showed inconsistent results, which might have been due to different inclusion criteria for the two studies (Singh et al, 2013; Wang et al, 2014). Furthermore, in a recent randomised clinical trial, addition of a conventional anti-diabetic dose of metformin does not improve outcome in patients with advanced pancreatic cancer treated with gemcitabine and erlotinib (Kordes et al, 2015), although significantly negative association of metformin with cancer were showed in vitro, in vivo studies (Cifarelli et al, 2015; Tan et al, 2015; Yue et al, 2015) or in epidemiological studies (Evans et al, 2005). Similar inconsistencies were found in another three meta-analyses on insulin, or sulfonylurea and pancreatic cancer (Soranna et al, 2012; Singh et al, 2013). In addition, two published randomised clinical trials were underpowered and provided non-significant results with wide, non-informative $95 \%$ CIs (Home et al, 2010). The considerable heterogeneity between studies, for example, study design, setting or comparator drugs, might explain the different results. Furthermore, confounding by indication and reverse causality cannot be ruled out in almost all of these original studies. 
In our study, the positive association of diabetes or anti-diabetic medication use with a risk of pancreatic cancer could not be fully differentiated from each other because of time-related bias and confounding by indication. However, the results based on elevated $\mathrm{HbA1c}$ levels seem to further corroborate the role of diabetes itself rather than the use of anti-diabetic medication in the aetiology of pancreatic cancer. Specifically, our study indicates the magnitude of pancreatic cancer risk in different anti-diabetic medications, which ranked from slightly increased to higher ORs for the following medications: metformin, sulphonylurea, a combination of oral anti-diabetic medications, and finally, insulin. One cannot exclude that part of the increased risk among insulin users is due to confounding by indication. However, the magnitude of the association favours an independent role of the medication per se, in addition to the severity of disease. The underlying mechanism of the slightly least increased risk in metformin users compared with other diabetic medications has been demonstrated in experimental studies. Metformin may disrupt a crosstalk between insulin receptor and other growth-factor signalling systems in human pancreatic cancer cells (Kisfalvi et al, 2009). An interesting piece of new information is that the administration of metformin seems to block mammalian target of rapamycin (mTOR) activity and inhibit the growth of human pancreatic cancer cells in some animal models (Rozengurt, 2014).

Strengths of our study include the population-based cohort study design, validated pancreatic cancer diagnosis, and detailed prospective information on drug exposure and potential confounding factors. The source of the study population, the THIN database, is representative of the UK population and has been validated for use in epidemiological studies (Bourke et al, 2004; Lewis et al, 2007). The use of administrative register data may, however, result in ascertainment bias with an under appreciation or misclassification of diabetes or pancreatic cancer, although this bias may be minor because the administrative data were validated by the reviewing of medical records. Histological confirmation of coded pancreatic cancer diagnoses was not available, raising the possibility that some pancreatic cancers may have been misclassified, and whether such misclassification could be differential or non-differential cannot be determined. Furthermore, missing data on $\mathrm{HbA1c}$ levels may bias the results, although availability of $\mathrm{HbAlc}$ was reasonably distributed from the time of diabetes diagnosis. Further studies with completely dynamic information of $\mathrm{HbAlc}$ are warranted to verify the current findings. Finally, our study was limited by a lack of dietary history, which may potentially confound the results. As the causality of pancreatic cancer is largely unclear, residual confounding by unknown risk factors may result in chance errors.

In conclusion, these data suggest that new-onset diabetes or elevated HbAlc levels after diabetes confers an increased risk of pancreatic cancer. Specific anti-diabetic medications carry different risks of pancreatic cancer, with a particularly increased risk among insulin users, and gradually less increased risks among users of combination of oral anti-diabetic medications, sulphonylurea and metformin, although these associations warrant further research.

\section{ACKNOWLEDGEMENTS}

We acknowledge the financial support provided by the Swedish Research Council, Karolinska Institutet and the Swedish Society of Medicine for this study.

\section{CONFLICT OF INTEREST}

The authors declare no conflict of interest.

\section{AUTHOR CONTRIBUTIONS}

Yunxia Lu, Luis Alberto García Rodríguez and Tomas S Bexelius: conceptualisation and design; Luis Alberto García Rodríguez: data collection; Linnéa Malgerud: data preparation and review of medical records; Yunxia Lu, Luis Alberto García Rodríguez and Antonio González-Pérez: data analysis; all: reporting of results and interpretation of data; Yunxia Lu: drafting of manuscript; all: contribution to critical comments and revisions, and final approval of the version to be published.

\section{REFERENCES}

Aggarwal G, Ramachandran V, Javeed N, Arumugam T, Dutta S, Klee GG, Klee EW, Smyrk TC, Bamlet W, Han JJ, Rumie Vittar NB, de Andrade M, Mukhopadhyay D, Petersen GM, Fernandez-Zapico ME, Logsdon CD, Chari ST (2012) Adrenomedullin is up-regulated in patients with pancreatic cancer and causes insulin resistance in beta cells and mice. Gastroenterology 143(6): 1510-1517.

Ben Q, Xu M, Ning X, Liu J, Hong S, Huang W, Zhang H, Li Z (2011) Diabetes mellitus and risk of pancreatic cancer: a meta-analysis of cohort studies. Eur J Cancer 47(13): 1928-1937.

Bosetti C, Rosato V, Li D, Silverman D, Petersen GM, Bracci PM, Neale RE, Muscat J, Anderson K, Gallinger S, Olson SH, Miller AB, Bas Bueno-de-Mesquita H, Scelo G, Janout V, Holcatova I, Lagiou P, Serraino D, Lucenteforte E, Fabianova E, Ghadirian P, Baghurst PA, Zatonski W, Foretova L, Fontham E, Bamlet WR, Holly EA, Negri E, Hassan M, Prizment A, Cotterchio M, Cleary S, Kurtz RC, Maisonneuve P, Trichopoulos D, Polesel J, Duell EJ, Boffetta P, La Vecchia C (2014) Diabetes, antidiabetic medications, and pancreatic cancer risk: an analysis from the International Pancreatic Cancer Case-Control Consortium. Ann Oncol 25(10): 2065-2072.

Bourke A, Dattani H, Robinson M (2004) Feasibility study and methodology to create a quality-evaluated database of primary care data. Inform Prim Care 12(3): 171-177.

Bowker SL, Majumdar SR, Veugelers P, Johnson JA (2006) Increased cancerrelated mortality for patients with type 2 diabetes who use sulfonylureas or insulin. Diabetes Care 29(2): 254-258.

Boyle P, Boniol M, Koechlin A, Robertson C, Valentini F, Coppens K, Fairley LL, Boniol M, Zheng T, Zhang Y, Pasterk M, Smans M, Curado MP, Mullie P, Gandini S, Bota M, Bolli GB, Rosenstock J, Autier P (2012) Diabetes and breast cancer risk: a meta-analysis. Br J Cancer 107(9): 1608-1617.

Chari ST (2014) New-onset diabetes: a clue to the early diagnosis of pancreatic cancer. JOP 15(5): 2778.

Cifarelli V, Lashinger LM, Devlin KL, Dunlap SM, Huang J, Kaaks R, Pollak MN, Hursting SD (2015) Metformin and Rapamycin reduce pancreatic cancer growth in obese prediabetic mice by distinct microRNA-regulated mechanisms. Diabetes 64(5): 1632-1642.

El-Serag HB, Hampel H, Javadi F (2006) The association between diabetes and hepatocellular carcinoma: a systematic review of epidemiologic evidence. Clin Gastroenterol Hepatol 4(3): 369-380.

Elena JW, Steplowski E, Yu K, Hartge P, Tobias GS, Brotzman MJ, Chanock SJ, Stolzenberg-Solomon RZ, Arslan AA, Bueno-de-Mesquita HB, Helzlsouer K, Jacobs EJ, LaCroix A, Petersen G, Zheng W, Albanes D, Allen NE, Amundadottir L, Bao Y, Boeing H, Boutron-Ruault MC, Buring JE, Gaziano JM, Giovannucci EL, Duell EJ, Hallmans G, Howard BV, Hunter DJ, Hutchinson A, Jacobs KB, Kooperberg C, Kraft P, Mendelsohn JB, Michaud DS, Palli D, Phillips LS, Overvad K, Patel AV, Sansbury L, Shu XO, Simon MS, Slimani N, Trichopoulos D, Visvanathan K, Virtamo J, Wolpin BM, Zeleniuch-Jacquotte A, Fuchs CS, Hoover RN, Gross M (2013) Diabetes and risk of pancreatic cancer: a pooled analysis from the pancreatic cancer cohort consortium. Cancer Causes Control 24(1): 13-25.

Evans JMM, Donnelly LA, Emslie-Smith AM, Alessi DR, MOrris AD (2005) Metformin and reduced risk of cancer in diabetic patients. BMJ 330: 1304-1305.

Farmer A (2012) Use of HbA1c in the diagnosis of diabetes. BMJ 345: e7293. Flood A, Strayer L, Schairer C, Schatzkin A (2010) Diabetes and risk of incident colorectal cancer in a prospective cohort of women. Cancer Causes Control 21(8): 1277-1284. 
Friberg E, Orsini N, Mantzoros CS, Wolk A (2007) Diabetes mellitus and risk of endometrial cancer: a meta-analysis. Diabetologia 50(7): 1365-1374.

Giovannucci E, Harlan DM, Archer MC, Bergenstal RM, Gapstur SM, Habel LA, Pollak M, Regensteiner JG, Yee D (2010) Diabetes and cancer: a consensus report. Diabetes Care 33(7): 1674-1685.

Gonzalez-Perez A, Schlienger RG, Rodriguez LA (2010) Acute pancreatitis in association with type 2 diabetes and antidiabetic drugs: a population-based cohort study. Diabetes Care 33(12): 2580-2585.

Grote VA, Rohrmann S, Nieters A, Dossus L, Tjonneland A, Halkjaer J, Overvad K, Fagherazzi G, Boutron-Ruault MC, Morois S, Teucher B, Becker S, Sluik D, Boeing H, Trichopoulou A, Lagiou P, Trichopoulos D, Palli D, Pala V, Tumino R, Vineis P, Panico S, Rodriguez L, Duell EJ, Molina-Montes E, Dorronsoro M, Huerta JM, Ardanaz E, Jeurnink SM, Beulens JW, Peeters PH, Sund M, Ye W, Lindkvist B, Johansen D, Khaw KT, Wareham N, Allen N, Crowe F, Jenab M, Romieu I, Michaud DS, Riboli E, Romaguera D, Bueno-de-Mesquita HB, Kaaks R (2011) Diabetes mellitus, glycated haemoglobin and C-peptide levels in relation to pancreatic cancer risk: a study within the European Prospective Investigation into Cancer and Nutrition (EPIC) cohort. Diabetologia 54(12): 3037-3046.

Home PD, Kahn SE, Jones NP, Noronha D, Beck-Nielsen H, Viberti G. Adopt Study Group, Record Steering Committee (2010) Experience of malignancies with oral glucose-lowering drugs in the randomised controlled ADOPT (A Diabetes Outcome Progression Trial) and RECORD (Rosiglitazone Evaluated for Cardiovascular Outcomes and Regulation of Glycaemia in Diabetes) clinical trials. Diabetologia 53(9): 1838-1845.

Hsueh WA, Orloski L, Wyne K (2010) Prediabetes: the importance of early identification and intervention. Postgrad Med 122(4): 129-143.

Karlstad O, Starup-Linde J, Vestergaard P, Hjellvik V, Bazelier MT, Schmidt MK, Andersen M, Auvinen A, Haukka J, Furu K, de Vries F, De Bruin ML (2013) Use of insulin and insulin analogs and risk of cancer - systematic review and meta-analysis of observational studies. Curr Drug Saf 8(5): 338-348.

Kisfalvi K, Eibl G, Sinnett-Smith J, Rozengurt E (2009) Metformin disrupts crosstalk between $\mathrm{G}$ protein-coupled receptor and insulin receptor signaling systems and inhibits pancreatic cancer growth. Cancer Res 69(16): 6539-6545.

Kordes S, Pollak MN, Zwinderman AH, Mathôt RA, Weterman MJ, Beeker A, Punt CJ, Richel DJ, Wilmink JW (2015) Metformin in patients with advanced pancreatic cancer: a double-blind, randomised, placebocontrolled phase 2 trial. Lancet Oncol 16(7): 839-847.

Kowall B, Rathmann W, Kostev K (2015) Are sulfonylurea and insulin therapies associated with a larger risk of cancer than metformin therapy? a retrospective database analysis. Diabetes Care 38(1): 59-65.

Lee JY, Jeon I, Lee JM, Yoon JM, Park SM (2013) Diabetes mellitus as an independent risk factor for lung cancer: a meta-analysis of observational studies. Eur J Cancer 49(10): 2411-2423.

Lewis JD, Schinnar R, Bilker WB, Wang X, Strom BL (2007) Validation studies of the health improvement network (THIN) database for pharmacoepidemiology research. Pharmacoepidemiol Drug Saf 16(4): 393-401.

Michaud DS, Wolpin B, Giovannucci E, Liu S, Cochrane B, Manson JE, Pollak MN, Ma J, Fuchs CS (2007) Prediagnostic plasma C-peptide and pancreatic cancer risk in men and women. Cancer Epidemiol Biomarkers Prev 16(10): 2101-2109.

Onitilo AA, Berg RL, Engel JM, Glurich I, Stankowski RV, Williams G, Doi SA (2013) Increased risk of colon cancer in men in the pre-diabetes phase. PLoS One 8(8): 70426.
Pannala R, Basu A, Petersen GM, Chari ST (2009) New-onset diabetes: a potential clue to the early diagnosis of pancreatic cancer. Lancet Oncol 10(1): 88-95.

Pannala R, Leirness JB, Bamlet WR, Basu A, Petersen GM, Chari ST (2008) Prevalence and clinical profile of pancreatic cancer-associated diabetes mellitus. Gastroenterology 134(4): 981-987.

Rozengurt E (2014) Mechanistic target of rapamycin (mTOR): a point of convergence in the action of insulin/IGF-1 and G protein-coupled receptor agonists in pancreatic cancer cells. Front Physiol 5: 357.

Sah RP, Nagpal SJ, Mukhopadhyay D, Chari ST (2013) New insights into pancreatic cancer-induced paraneoplastic diabetes. Nat Rev Gastroenterol Hepatol 10(7): 423-433.

Singh S, Singh PP, Singh AG, Murad MH, McWilliams RR, Chari ST (2013) Anti-diabetic medications and risk of pancreatic cancer in patients with diabetes mellitus: a systematic review and meta-analysis. Am J Gastroenterol 108(4): 510-519.

Sjoberg Bexelius T, Garcia Rodriguez LA, Lindblad M (2009) Use of angiotensin II receptor blockers and the risk of acute pancreatitis: a nested case-control study. Pancreatology 9(6): 786-792.

Soranna D, Scotti L, Zambon A, Bosetti C, Grassi G, Catapano A, La Vecchia C, Mancia G, Corrao G (2012) Cancer risk associated with use of metformin and sulfonylurea in type 2 diabetes: a meta-analysis. Oncologist 17(6): 813-822.

Stolzenberg-Solomon RZ, Graubard BI, Chari S, Limburg P, Taylor PR, Virtamo J, Albanes D (2005) Insulin, glucose, insulin resistance, and pancreatic cancer in male smokers. JAMA 294(22): 2872-2878.

Tabak AG, Herder C, Rathmann W, Brunner EJ, Kivimaki M (2012) Prediabetes: a high-risk state for diabetes development. Lancet 379(9833): 2279-2290.

Tan XL, Bhattacharyya KK, Dutta SK, Bamlet WR, Rabe KG, Wang E, Smyrk TC, Oberg AL, Petersen GM, Mukhopadhyay D (2015) Metformin suppresses pancreatic tumor growth with inhibition of NFאB/STAT3 inflammatory signaling. Pancreas 44(4): 636-647.

Walker EJ, Ko AH, Holly EA, Bracci PM (2015) Metformin use among type 2 diabetics and risk of pancreatic cancer in a clinic-based case-control study. Int J Cancer 136(6): E646-E653.

Wang Z, Lai ST, Xie L, Zhao JD, Ma NY, Zhu J, Ren ZG, Jiang GL (2014) Metformin is associated with reduced risk of pancreatic cancer in patients with type 2 diabetes mellitus: a systematic review and meta-analysis. Diabetes Res Clin Pract 106(1): 19-26.

Wolpin BM, Bao Y, Qian ZR, Wu C, Kraft P, Ogino S, Stampfer MJ, Sato K, Ma J, Buring JE, Sesso HD, Lee IM, Gaziano JM, McTiernan A, Phillips LS, Cochrane BB, Pollak MN, Manson JE, Giovannucci EL, Fuchs CS (2013) Hyperglycemia, insulin resistance, impaired pancreatic beta-cell function, and risk of pancreatic cancer. J Natl Cancer Inst 105(14): 1027-1035.

Yue W, Zheng X, Lin Y, Yang CS, Xu Q, Carpizo D, Huang H, DiPaola RS, Tan XL (2015) Metformin combined with aspirin significantly inhibit pancreatic cancer cell growth in vitro and in vivo by suppressing antiapoptotic proteins Mcl-1 and Bcl-2. Oncotarget 6(25): 21208-21224.

Yoon JM, Son KY, Eom CS, Durrance D, Park SM (2013) Pre-existing diabetes mellitus increases the risk of gastric cancer: a meta-analysis. World J Gastroenterol 19(6): 936-945.

This work is published under the standard license to publish agreement. After 12 months the work will become freely available and the license terms will switch to a Creative Commons AttributionNonCommercial-Share Alike 4.0 Unported License.

Supplementary Information accompanies this paper on British Journal of Cancer website (http://www.nature.com/bjc) 